Agro-Science Journal of Tropical Agriculture, Food, Environment and Extension Volume 9 Number 3 September 2010 pp. 215-222

ISSN 1119-7455

\title{
WOMEN MARKETERS' PERCEIVED CONSTRAINTS ON SELECTED AGRICULTURAL PRODUCE MARKETING IN ENUGU SOUTH AREA: CHALLENGES OF EXTENSION TRAINING FOR WOMEN GROUPS IN ENUGU STATE, NIGERIA
}

\author{
Eze $^{1}$ S.O., Onwubuya ${ }^{2}$ E.A and Ezeh $^{3}$ A.N \\ ${ }^{1}$ Dept of Agricultural Economics, Management and Extension Ebonyi State University, \\ P.M.B 053 Abakaliki, Nigeria. \\ ${ }^{2}$ Department of Agricultural Extension University of Nigeria, Nsukka, Nigeria.
}

\begin{abstract}
Women constitute great apostles in agricultural production, processing, utilization and marketing as well as national economic growth. Given the increasing demands for basic crop products such as garri and milled rice in the diets of most households in Enugu south area, Nigeria, the marketing situation seems to be low relative to distribution. In this regard, this study investigated women marketers' perceived constraints on marketing of milled rice and garri in Enugu south area and highlighted challenges of extension training for women groups in Enugu State, Nigeria. One hundred and sixty randomly selected women marketers in Enugu South area constituted the sample size for the study. Structured interview schedule was employed in data collection.Frequency counts, percentage and factor analysis technique were the analytical tools adopted. The findings revealed that majority (63.8\%) of the women were within the ages of 31-50 years, while majority (75.5\%) have 6-20 years of marketing experience and $69.4 \%$ of them have equity capital of $\$ 5,001.00-$ 145,000.00. The major constraints perceived by the women included inadequate processing skill, produce deterioration and lack of storage facilities. The study highlighted challenges for extension training in women groups on improved government budgetary allocation to ADP, organizational overhaul and re-orientation in the ADP and women group mobilization with focus on groups for extension training and contact. In conclusion, success in agricultural produce marketing in Enugu South area and associated marketing extension training for women groups in Enugu State, Nigeria depend on the extent constraint issues raised and challenges thereof highlighted can be addressed.
\end{abstract}

Keywords: Agricultural produce marketing, Extension training, women marketers

\section{INTRODUCTION}

Agricultural produce marketing is an integral and crucial part of food production process in a viable farm enterprise. Agricultural produce marketing is viewed as the flow of goods and services from the point of initial farm production to the hands of the ultimate consumer (Adekanye 1988; Kohls and Uhi, 1990; AMA, 1994; Bibagambah, 1996). Onyeabor (2009) added that agricultural produce marketing depicts a process of demands and motivation of sellers to distribute food items unto ultimate consumers at a profit. According to Agbarevo and Obinne (2010) Agricultural marketing extension is fundamental to agricultural produce marketing and a process of training the farmers on best ways to acquire farm inputs and distribute the output to maximize profit. Between the colonial era of the 1950s and since Nigerian's political independence in 1960, successive government administrations have made concerted efforts to improve marketing system. Specific among these performance improvement efforts of governments are by way of market liberalization policy and involvement of measures to encourage free entry and sustain the marketing system. The question is why have these government efforts in agricultural produce marketing in Nigeria not yielded the desired results in achieving the desired contributions of the agricultural sector to the Gross Domestic Products (GDP)?

In Enugu South area of Enugu State, a teeming population of men and women play dynamic roles in agricultural food production and marketing as their necessary primary occupations and for economic development. These roles tend to be more in area of marketing rather than primary production basically because of scarcity of land and urbanization. Women constitute overwhelming population of those who are involved in agricultural produce marketing as against the men who focus more on artisan, subsistent farming and civil service 
occupations (ENADEP, 2009). These women are concerned as great apostles of household nutritional requirement of diets, management and income generation (Dianco-Adetayo, 2000). According to Adubi and Jibowo (2006) women are invisible workforce and the unacknowledged backbone of the family. However, given the increasing demands for garri and milled rice in the diets of most households in Enugu State, Nigeria and Enugu South area in particular, the marketing situation seems to be low relative to distribution. Under multi-sectoral approach to food security, economic empowerment and poverty reduction marketing has challenges to extension. These challenges of effective agricultural produce marketing supported by sustainable marketing extension training for women groups are responsibilities which the Agricultural Development Programme (ADP) perform. Women marketers' perception of constraints on agricultural produce marketing of garri and processed rice is fundamental to the reality of their socio-economic conditions. The desirable social and economic condition are basic for adjustment and useful challenges for group participation in extension training for food security and economic development policy.

The socio-economic background of farmers constitute critical input to extension training needed to improve entrepreneurship skills among farmers for effective processing, storage and distribution of their farm produce (Agbarevo and Obinne 2010). What are the socio-economic characteristics of women marketers in Enugu South area of Enugu State?. Jeans (1998) has recommended the need for extension training in order to improve entrepreneurship and understanding of marketing opportunities among farmers and the cost and benefits in the marketing process as necessary in optimizing their income. According to Agbarevo and Obinne (2010), low entrepreneurship skills and poverty among small-scale farmers in Nigeria are attributable to inadequate marketing extension training, poor distribution process and associated lack of adoption of other recommended farm practices. What are the distribution channels for garri and milled rice preferred by women marketers? What constraints do women marketers' perceive as responsible for achieving low performance targets? What specific lessons could be learned from women marketers' perceived constraints on marketing of garri and milled rice in Enugu South area that could serve as useful challenges of extension training for groups in Enugu State, Nigeria?

The overall purpose of this study was to determine women marketers' perceived constraints on selected agricultural produce marketing (garri and milled rice) in Enugu South area and highlight challenges of extension training for women groups in Enugu State, Nigeria. Specifically, the objectives were to; describe the socio-economic characteristics of garri and milled rice marketers and identify the distribution channels employed by them. Others include to; determine women marketers' perceived constraints on agricultural produce marketing in Enugu South area and highlight challenges of marketing extension training for women groups in Enugu State, Nigeria

\section{MATERIALS AND METHODS}

The study covered Enugu South area of Enugu State with eight communities namely; Obeagu-Ugwuaji, Obeagu-Etiti, Akwuke, Obeagu, Amechi-Awkunanaw, Ugwuaji, Amechi -Uwani and Akwuke-Uwani. Enugu South area has estimated population of one hundred and fifty-three thousand four hundred and seventy-three people (NPC, 2006). Over 90 percent of the inhabitants of the area are traders and about 70 percent of these traders are women (ENADEP 2009). Thus both women garri and milled rice marketers and non-marketers constituted the population for the study. Both purposive multistage and random sampling techniques were employed in data collection. Only garri and milled rice marketers whose list was obtained through the Enugu State Agricultural Development Programme (ENADEP) enumerators were purposively involved basically because of the prominence of garri and milled rice in the diets of households in the area. Multi stage random sampling technique was used to select the respondents. In the first stage, four communities namely; AmechiUgwuaji, Obeagu, Amechi-Awkunanaw; and Amechi-Uwani were randomly selected. In the second stage, four villages from each of the selected commodities were randomly involved, while in the third stage 10 women marketers from each of the villages involved were randomly selected. Thus a total of 160 women who engaged in garri and milled rice marketing constituted the sample size for the study.

An interview schedule for garri and milled rice marketers was developed, validated and employed for data collection. The interview schedule was organized in sections and reflected issues on socio-economic characteristics of women marketers, distribution channels and constraint issues in marketing. Analytical tools such as frequency counts, percentage, and factor analysis techniques were adopted. The exploratory factor analysis techniques using principal factor model with interactions and varimax rotation was adopted. The factor loading under each constraint (beta weight) 
represents a correlation of the variables (constraint areas) to the identified constraint factors and has the same interpretation as any correlation coefficient. Kaiser's criterion using factor loading of 0.30 and above in naming and interpreting the factors and constraint variables was adopted (Child 1978, Ogunfiditimi, 1979).

\section{RESULTS AND DISCUSSION}

Socio-Economic Characteristics of Women Marketers

Data in Table 1 show that majority $(63.8 \%)$ of the women agricultural produce marketers were within the ages of 31-50 years, while 63.8 percent of them were married. Majority $(77.5 \%)$ of the women had 6-15 members in their household, while large $(42.5 \%)$ numbers of them had either FSLC or WASC/SSCE/GCE/OL qualifications. The foregoing results indicate that most women who engage in agricultural produce marketing (milled rice and garri) in Enugu South area of Enugu State were adults but they had low formal educational attainment. Earlier research reports by Nwaru and Iwuji (2005) showed that education has positive relationship with marketing margin because of its training advantages which help the marketers to be informed, innovating and averse to marketing risks. Thus the situation of low educational attainment revealed by this study could affect negatively efficiency in marketing among the women due to possible lag in resource use among other things.

Majority (79.5\%) of the women have 620years of milled rice and garri marketing experience, while 69.4 percent of them have estimated equity capital of $\$ 5,001.00$ $\$ 45,000.00$. and large $(50.0 \%)$ numbers of the women engaged in full-time marketing occupation. Equity capital indicates the farmers' owned investment capital expressed as a percentage of the total assets of the business enterprises (Ezike, Nwibo and Odoh 2009). With the women marketers' estimated equity capital of $\$ 5,001.00-\$ 45,000.00$ revealed by this study, marketing of Agricultural produce such as milled rice and garri in Enugu South area is affordable, interesting and demand- driven. This study therefore, agrees with those of Usman, Omoayena and Ishaya (2006) who reported that a business enterprises equity capital of $\$ 6$, 000.00 and above is good and affordable to all individuals and interest groups.

Women marketers' Preferred Channels of
Distribution in Agricultural Produce
Marketing of Milled Rice and Garri.

Table 2 indicates that majority $(72.2 \%)$ of milled rice marketers and 75.9 percent of those who market garri preferred indirect distribution channels in their marketing business. Specific indirect distribution channels employed by the women in Enugu South area of Enugu State include, decentralized distribution with 8.3 percent for milled rice and 12.1 percent for garri marketers, wholesale/bulk purchase $(12.7 \%)$ for milled rice and (12.6\%) for garri and commissioned middlemen $(11.9 \%)$ for milled rice and (11.5\%) for garri. Other indirect distribution channels include; free entry/uncommissioned middlemen (14.4\%) for garri and 13.9 percent for milled rice marketers. The foregoing situation is synonymous to diverse distribution channels which could guarantee all season availability of milled rice and garri necessary in achieving the desirable responsiveness of the marketing system to demand based on affordable price among consumers. This study therefore, agrees with those of Anumuibe and Eze (2002) as well as Nwaru and Iwuji (2005) who viewed marketdriven economic efficiency as market responsiveness to price due to all season availability of goods and choice among the consumers.

Table 2 also shows other specific indirect distribution channel as; retailer with 25.4 percent for milled rice and 25.3 percent for garri. Only 27.7 percent of women under milled rice and 24.1 percent of them under garri preferred direct distribution of either centralized or farm gate channels. These marketers who preferred direct contacts with producers at centralized and farm gate channels as revealed by this study would buy at cheaper prices with advantage of bulk purchases but would require greater resources use for efficiency. Evidently direct distribution marketers would need biochemical and other measures for appropriate processing and assemblage in order to ensure sustainable storage and marketing (Iheanacho and Abdulahi 2006). 
Table 1: Percentage Distribution of Women Marketers of Milled Rice and Garri According to Their Socio-Economic Characteristics.

\begin{tabular}{|c|c|c|c|}
\hline Variables & Categories & Frequency $(\mathrm{N}=160)$ & Percentage (\%) \\
\hline \multirow[t]{3}{*}{ Marital status } & Single & 34 & 21.2 \\
\hline & Married & 10.2 & 63.8 \\
\hline & Widowed & 17 & 10.6 \\
\hline \multirow[t]{7}{*}{ Age of women (yrs) } & Separated & 7 & 4.4 \\
\hline & $\leq 20$ & 11 & 4.1 \\
\hline & $21-30$ & 33 & 20.1 \\
\hline & $31-40$ & 38 & 20.8 \\
\hline & $41-50$ & 64 & 40.0 \\
\hline & $51-60$ & 12 & 7.5 \\
\hline & 61 years and above & 12 & 7.5 \\
\hline \multirow[t]{4}{*}{ Household size (No) } & $\leq 5$ & 25 & 15.6 \\
\hline & $6-10$ & 108 & 67.5 \\
\hline & $11-15$ & 16 & 10.0 \\
\hline & 16 and above & 11 & 6.9 \\
\hline \multirow[t]{5}{*}{ Level of formal education } & No formal Edu & 60 & 37.5 \\
\hline & FSLC & 40 & 25.0 \\
\hline & WASC/SSCE/GCE/O/L & 28 & 17.5 \\
\hline & $\mathrm{OND} / \mathrm{NCE}$ & 21 & 13.1 \\
\hline & HND/BA/B.SC/BED & 11 & 6.9 \\
\hline \multirow[t]{5}{*}{ Marketing experience (yrs) } & $\leq 5$ & 20 & 10.5 \\
\hline & $6-10$ & 78 & 48.0 \\
\hline & $11-15$ & 40 & 24.0 \\
\hline & $16-20$ & 12 & 7.5 \\
\hline & 21 yrs and above & 10 & 10.0 \\
\hline \multirow[t]{5}{*}{ Equity capital ( $)$} & $\leq 5,000.00$ & 13 & 8.1 \\
\hline & $5,001.00-25,000.00$ & 40 & 25.0 \\
\hline & $25,001.00-45,000.00$ & 71 & 44.4 \\
\hline & $45,001.00-65,000.00$ & 31 & 19.4 \\
\hline & $65,001.00$ and above & 5 & 3.1 \\
\hline \multirow[t]{5}{*}{ Occupation } & Full time farming & 12 & 7.4 \\
\hline & Public service & 14 & 8.8 \\
\hline & Artisian & 30 & 18.8 \\
\hline & Full -time trading & 80 & 50.0 \\
\hline & Student & 24 & 15.0 \\
\hline
\end{tabular}

Source: Field Survey 2010.

Table 2: Percentage Distribution of Women According to Their Preferred Marketing Channels for Milled Rice and Garri.

\begin{tabular}{|c|c|c|c|c|}
\hline \multirow[t]{2}{*}{ Distribution Channels } & \multicolumn{2}{|c|}{$\begin{array}{l}\text { Agricultural produce } \\
\text { milled rice }\end{array}$} & \multicolumn{2}{|c|}{ Garri } \\
\hline & Frequency & $\%$ & Frequency & $\%$ \\
\hline \multicolumn{5}{|l|}{ Direct distribution : } \\
\hline Centralized & 18 & 7.1 & 10 & 5.7 \\
\hline Farm gate & 52 & 20.6 & 32 & 18.4 \\
\hline \multicolumn{5}{|l|}{ Indirect distribution: } \\
\hline Decentralized middlemen & 21 & 8.3 & 21 & 12.1 \\
\hline Wholesales/bulk purchase middlemen & 32 & 12.7 & 22 & 12.6 \\
\hline Commissioned middlemen & 30 & 11.9 & 20 & 11.5 \\
\hline \multicolumn{5}{|c|}{ Free entry/uncommissioned competitive : } \\
\hline Middlemen & 35 & 13.9 & 25 & 14.4 \\
\hline Retailer channel & 64 & 25.4 & 44 & 25.3 \\
\hline
\end{tabular}

Source: Field Survey 2010. 


\section{Women Marketers' Perceived Constraints to Agricultural Produce Marketing (Milled Rice and Garri) in Enugu South area of Enugu State.}

Table 3 shows the varimax rotated factors perceived by women marketers' as constraints to Agricultural produce marketing of milled rice and garri in Enugu South area of Enugu State. Based on specific items loading, three major factors were extracted namely; factor 1 , inadequate processing skill,; factor 2, produce deterioration; and factor 3, lack of storage facilities. Specific issues which loaded high and amplified inadequate processing skill include; inadequate processing equipment (0.44), long distance to processing centres (0.45) and inadequate packaging information (0.55).Others include, poor technical know how of women marketers (0.42), and inadequate extension services (0.37). Proficiency in processing Agricultural produce such as rice and garri depend largely on the extent of participation and ownership of facilities among the marketers' as beneficiaries. This desirable participation on the part of agricultural produce marketers requires the will and aptitudes of the women. Inadequate processing skill depicts deficiencies on the part of women in the knowledge of processing and employment of necessary techniques. Inadequate processing equipment contributes to long distance to better processing/centers all of which worsen technical know how of marketers. Similarly, inadequate packaging information is blamable on inadequate extension services to women marketers all of which worsen the processing skills of milled rice and garri marketers.

Produce deterioration depicts depreciation from previous stage of production. This situation could arise because of inefficient processing or the inability of the women marketers to preserve their milled rice and garri in stable condition in Enugu South area of Enugu State, Nigeria. This study therefore agrees with Njoku and Obiefuna (1987) who attributed marketing problems such as price instability and high storage loses to produce deterioration. Produce deterioration could incapacitate the efforts of the women marketers in recovering their costs and retaining some unsold quantities for their household consumption. Specific produce deterioration issues include; poor marketing facilities (0.36), poor quality produce (0.52), unpredictable bad weather (0.49), environmental degradation (0.38) and inaccessibility to credit (0.51). Unpredictable bad weather amplifies environmental degradation and incompatible quality of milled rice and garri. Similarly, inaccessibility of women marketers to credit could affect negatively the marketing facilities they employ in business. Earlier research reports by Njoku (1994) has recommended improved marketing policy to involve improved marketing facilities such as stable packaging equipment and storage facilities. The more propensity the women have towards coexistence in groups the greater the accessibility of women marketers to credit. Accessibility of women marketers to credit enhance their aptitude in procuring good facilities needed to counter bad weather and environmental degradation in milled rice and garri marketing. This study also agrees with that of Nwaogwugwu, Adesope and Agumagu (2007) who reported inadequate access to credit as a serious obstacle to rural transformation, Agricultural production expansion and produce marketing in rural Nigeria.

Furthermore, Table 3 reveals lack of storage facilities as a major factor in Agricultural produce marketing in Enugu South area of Enugu State. This scenario depicts lack of preservation facilities and space where milled rice and garri could be kept and released for sale according to need. Specific issues which loaded high under lack of storage facilities include; high cost of shops (0.41), inadequate storage facilities (0.47), poor performance of women groups (0.39), poor preservation measure (0.34) and low equity capital $(0.40)$. Inadequate storage facilities and poor preservation measures are related problems which could be blamed on low equity capital of the women marketers. Similarly, poor performance of women groups coupled with high cost of shops amplifies lack of storage facilities as constraints among the women in marketing of milled rice and garri in Enugu South area of Enugu State. Evidently, successful marketing of perishable produce such as vegetables, milled rice and garri requires good marketing focus on preservation and storage facilities (Usman, Omoayena and Ishaya, 2006). This situation requires greater efforts on the part of women marketers to co-exist in groups for better performance in procuring preservation and storage facilities needed for marketing of milled rice and garri in Enugu South area of Enugu State. 
Table 3: Varimax Rotated Women Perceived Constraints on Agricultural Produce Marketing of Milled Rice and Garri

\begin{tabular}{llll}
\hline Constraint variables & Factor 1: Inadequate & Factor 2: & $\begin{array}{l}\text { Produce } \\
\text { Factor 3: Lack of Storage } \\
\text { Facilities }\end{array}$ \\
\hline Inadequate processing equipment & 0.44 & -0.11 & 0.22 \\
Long distance to processing centers & 0.45 & 0.09 & -0.02 \\
Poor marketing facilities & 0.09 & 0.36 & 0.07 \\
High cost of shops & -0.14 & -0.06 & 0.41 \\
Inadequate storage facilities & 0.29 & -0.23 & 0.47 \\
Poor quality produce & 0.04 & 0.52 & 0.01 \\
Inadequate packaging information & 0.55 & 0.03 & 0.18 \\
Poor performance of women groups & -0.35 & 0.02 & 0.39 \\
Poor technical know of women Farmers & 0.42 & 0.21 & -0.05 \\
Unpredictable bad weather & 0.21 & 0.49 & -0.04 \\
Inadequate government marketing policy & -0.39 & 0.27 & -0.07 \\
Environmental degradation & -0.16 & 0.38 & 0.23 \\
Incompatible preservation measures & -0.36 & 0.16 & 0.34 \\
Inadequate extension services & 0.37 & -0.21 & 0.09 \\
Inaccessibility to credit & 0.14 & 0.51 & 0.03 \\
Low equity capital & -0.09 & 0.12 & 0.40 \\
\hline Source: Field Survey, 2010. & & &
\end{tabular}

Challenges of Training for Women Groups in Enugu State, Nigeria.

There could be a consensus that the Nigerian agricultural marketing systems have undergone profound changes culminating in the present diverse marketing arrangement. These desirable changes have involved free entry and measures to counterbalance what used to cause weakness and failures of the traditional marketing system. However, the extent of goal attainment is doubtful in terms of involving meaningful market liberalization supported with critical rural infrastructure, provision of credit and mobilization of relevant groups through training to link with necessary marketing organizations. Hence this study identified constraints as fundamental issues among women marketers of milled rice and garri in Enugu South area of Enugu State namely; inadequate processing skills, produce deterioration and lack of storage facilities. The envisaged contributions of marketing system to MDGs demand conscious effort to harmonize necessary strategies and stimulate linkages between the government, relevant institutions and farmers as marketers. Examination against the backdrop of this study has challenges to budgetary allocation by government in order to elicit necessary agricultural extension training. The envisaged improvement in government budgetary allocation has challenges to emphasize critical market infrastructure, credit and support in order to make extension training more effective under the ADP as a grassroot- oriented organization. The ADP has remained the only grassroot oriented agricultural extension outfit in Enugu State.
The foregoing situation has challenges to government support for workable relationship between formidable organizations namely; Ministry of Agriculture (MOA), Credit institutions as well as commerce and industry with the ADP. The desirable relationship has challenges to the relevant Agricultural food production and market oriented organizations to adopt the ADP as their implementing arm. This is needed to enhance necessary training under the ADP, while concentrating efforts on primary production, processing and foster interest between market forces through strong synergy with the ADP. The envisaged synergy has challenges for organizational overhaul in the Enugu State ADP and in particular Enugu South Extension block to involve necessary educational programmes and improve staff skills, contacts and emphasize market -oriented training for women marketers in groups.

The envisaged overhaul has challenges of harmonization and co-operation between the ADP and Enugu South area to orientate and focus extension staff contacts on women groups, group's mobilization and resources management. The desirable group's resources management among women marketers has challenges to the ADP extension staff training on group dynamics in order to work with rural leadership and social organizations. This will serve as strategies to overtly overhaul and restructure them as well as improve group relationship to be truly effective in achieving desirable remunerative goals. Moreover, the restructuring process also has challenges to the ADP in mobilizing existing social groups and encouraging group approach to 
agricultural produce distribution as meaningful economic strategy necessary in milled rice and garri marketing in Enugu South area. The envisaged women group economic empowerment has training challenges among women marketers in negotiating their interests, accessing desirable credit and other infrastructure for sustainable agricultural produce marketing of garri and milled rice in Enugu State, Nigeria.

\section{CONCLUSION}

This study investigated women marketers' perceived constraints on selected Agricultural produce marketing (milled rice and garri) in Enugu South area and highlighted challenges to extension training for women groups in Enugu State, Nigeria. The study is based on the premise that women perceived constraints in a market driven economy such as Enugu State, Nigeria is fundamental for sustainable food security and poverty reduction. Results of this study indicate that low performance and nonachievement in terms of attribute contributions of market to MDG in Enugu South area of Enugu State, Nigeria are blamable on critical constraints namely; inadequate processing skills, produce deterioration and lack of storage facilities. The constraints were highlighted to challenge extension training for women groups on improved government budgetary allocation and support to the ADP. Others included organizational overhaul and re-orientation in the ADP and availability of woman groups for extension contacts and training. Based on the foregoing, the study recommends improved government budgetary provisions with emphasis on critical market infrastructure. Others include, involvement of social groups, group dynamics and strategies to improve group leadership on the part of ADP and groups' resources management among the women marketers.

\section{REFERENCES}

Adekanye, T, (1988). Reading in Agricultural Economic; London ; Longamn Group Ltd. pp.

Adubi, K.O; and A.A. Jibowo; (2006). Perception of Women on their role Performance and the Relevance in Promoting Rural Development in Osun State, Nigeria; Nigerian Journal of Rural Sociology ;.6, $1 \& 2$; pp 49-54

Agbarevo, M.N.B; and C.P.O Obinne; (2010). Agricultural Marketing Extension; Elements of Rural Sociology and
Agricultural Extension; Uwani-Enugu, Teo Publishers; pp.190-198.

American Marketing Association; (AMA) (1994) 1994Agricultural Economics and Agribusines; $7^{\text {th }}$ edition; John willey and Sons, Inc. New York; Chichester Weinhein Brisbane Singapor; Toronto; pp.5-11.

Anumuibe, E.C. and C.C. Eze; (2002). Costreturns Analysis of Onion Marketing and Conflict Resolution; In: Iloeje, M.U; G.E Osuji; U. Herbert; and G.N. Asumugba (eds); Proceedings of $36^{\text {th }}$ Annual Conference of Agricultural Society of Nigeria. FUT, Owerri, Oct 20-24; pp.4952.

Bibagambah, J.R; (1996). Marketing of Small holder Crops in Uganda; Kampala Uganda. Fountain Publishers Ltd; pp.6469.

Child, D; (1978). The Essentials of Factor Analysis. New York, Holt Rinahanrt and Wilstarm Ltd. pp.

Dionco-Adetayo, F.A (2000). "Developing Entrepreneurial Characteristics of Women in Agro-industry: A Remedial Measure for Poverty Alleviation in Rural Nigeria", Agricultural Extension and Poverty Alleviation in Nigeria; In: Olowu, T.A (ed); Proceedings of the $6^{\text {th }}$ Annual National Conference of the Agricultural Extension Society of Nigeria. $10^{\text {th }}-12^{\text {th }}$ April; pp. 89-97.

ENADEP; (2009). Enugu State Agricultural Development Programme; Annual Report; 36pp.

Ezike, K.N.N; S.U. Nwibo and N.E. Odoh; (2009). Capital in Agricultural production: Acquisition Utilization and Management; Agribusiness and Finance; Enugu; John Jacob's Classic Publishers Ltd; pp. 163-188.

Jeans, A; (1998). An Enterprising Approach to Livelihood Strategies; PLA Note; London; IIED, October; pp.40-44.

Iheanacho, A.C. and A.B Abdullahi; (2006). Food security; The Opportunities and Challenges of Bio-Technology in Nigeria; In: Shoal A.O. Adepoju and Bola Okuneye (eds.) Technology and Agricultural Development in Nigeria; Proceeding of the $20^{\text {th }}$ Annual Conference of the Farm Management Association of Nigeria $18^{\text {th }}-21^{\text {st }}$ Sept; pp.219-223. 
Kohls, R. L; and J.N: Uhi; (1990). Marketing of Agricultural Products; $3^{\text {rd }}$ edition; MacMillan Publishing co; New York; pp.63.- 101.

Njoku, J.E; (1994). "The Economics of Wholesale Marketing of Vegetables in Owerri of Southern Nigeria:, The case of Onions; Tropical Agriculture; Trinidad;. 7; (2): 139- 143

Njoku , J.E; and J.C. Obiefuna; (1987). "Problems in Production and Marketing Agricultural Products in Imo State of Nigeria; Proceedings of the First National Workshop on Cocoyam Production NRCRI, Ummdike, Umahia; August 1621; pp.141-142.

NPC; (2006). National Population Commission. Estimated Population Census for Enugu State.

Usman, M.B; B.O; Omoayena and B.T. Ishaya. (2006). Marketing Analysis of Cabbage (Bracica Alleracea) in Jos South Local Government Area of Plateau State. In: Shola A.O. Adepoju and Peter Bola Okuneye (eds.) Technology and Agricultural Development in Nigeria. Proceedings of the $20^{\text {th }}$ Annual Conference of the Farm Management Association of Nigeria (FAMAN). $18^{\text {th }}$ $21^{\text {st }}$ September; pp 217-280
Nwaru, J.C; and O. Iwuji; (2005). Marketing Margins and their Determinants in Plantain Marketing in Owerri Agricultural Zone of Imo State, Nigeria; Agricultural Rebirth for Improved Production in Nigeria; In: Orherliata, A.M; S.O. Nwokoro; M.T. Ajayi; A.T. Adekunle and G.N. Asumugha (eds); Proceedings of the $39^{\text {th }}$ Annual Conference of the Agricultural Society of Nigeria. University of Benin, Benin City. Oct $9^{\text {th }}-13^{\text {th }} ;$ pp $385-387$

Ogunfiditimi, I.J.O; (1979). Construction of Five Factor Attitude for Evaluation of the Food for Work Programme; Journal of social Psychology; 187: 25-33

Onyeabor, E. N; (2009). Marketing and Distribution Channels; Agricultural Marketing for Developing Economies; Enugu John Jacob's Classic Publishers Ltd; pp.14-25. 